\title{
The Culture of Othering: An Interrogation of Shakespeare's Handling of Race and Ethnicity in The Merchant of Venice and Othello
}

\author{
Mika Nyoni \\ Great Zimbabwe University, Masvingo, Zimbabwe \\ Email: mikanyoni@gmail.com
}

\begin{abstract}
This paper examines Shakespeare's handling of the issue of race in The Merchant of Venice and Othello. Race and ethnicity have been at the epicentre of many conflicts throughout history and are still a headache even in $21^{\text {st }}$ century societies that boast of unprecedented technological advancement and sophisticated lifestyles. Shakespeare has been used as a touchstone in many literary communities --playwrights and poets have been measured against his writings and the academic diets of pupils and students alike in many countries have always included a dish from the 'Chief Chef', Shakespeare. There is no doubt that his works entertained as well as educated many, his contemporaries as well as later generations across cultures but did the curriculum content of his education always inculcate virtue? Wasn't the entertainment at the expense of certain individuals because of their background? Through close reference to the plays The Merchant of Venice and Othello, this paper argues that the revered artist was racially intolerant and his writings may have influenced or helped to perpetuate racism and religious bigotry which was evident in The Slave Trade, Colonialism and the persecution of Jews in Germany. Some of his works therefore not only entertain(ed) and instruct(ed) but also misentertain(ed) and misinstruct(ed).
\end{abstract}

Index Terms - Shakespeare, race, ethnicity, The Merchant of Venice, Othello

\section{INTRODUCTION}

This article takes a close look at The Merchant of Venice and Othello by Shakespeare who is regarded as unparalleled in his literary prowess. His poems and plays are still read, acted and immensely enjoyed the world over centuries after they were written. In many countries, and very certainly in the former British colonies, one could not be regarded as having done Literature in English without having studied works by Shakespeare. In fact even at primary school 'prosified' and shortened versions of his plays were included yet close scrutiny of his literary products reveals astonishing levels of racism and religious bigotry among other vices. This article interrogates Shakespeare's handling of the issue of race in The Merchant of Venice and Othello using an Afrocentric approach.

\section{AFROCENTRIC CRITICISM}

According to Simon During this approach is driven by 'the need, in nations or groups which have been victims of imperialism to achieve an identity uncontaminated by Universalist or Eurocentric concepts or images' (www.enotes.com/../introduction accessed on 18/11/09). Afrocentric writing or criticism exhibits an African-centred consciousness which is based on a profound understanding of the culture and cosmology of African peoples against such colonial practices as exploitation and slavery (Ngara, 1990). This literary theory has its roots in Negritude that many African critics consider the starting point of any cultural and literary response of the African to European domination. Negritude, a term coined by Caribbean writer and politician, Aimé Cesaire, signifies Africa's reawakening from the deep slumber of colonial domination and marginalization. The main postulates of the movement in Africa were Leopold Senghor and David Diop. The movement asserted African values and sought to challenge the colonialists who had made the African accept colonial rule as God-given, as an act of philanthropy and as legitimate thus making the African a willing and co-operating passenger on the voyage of self-denial and totally denigrating his/her own language, culture and identity. After generations of colonization and subnegation the Africans realized that they had something to be proud of after all and that there was nothing wrong with their race, colour and cultural practices as they were led to believe by their conquerors and sorcerers through carefully calculated curriculum concoctions to achieve what Ngugi refers to as 'cultural genocide' (Ngugi, 1981.p.14). Leading European thinkers traded the racist formulations which arguably helped to shape subsequent Anglo-Saxon thinking. David Hume in 1735 asserted:

The Negro is naturally inferior to the whites. There scarcely ever was a civilized nation of that complexion, nor even any individual, eminent either in action or speculation. No ingenious manufactures among them, no arts, no science...(cited in Ngugi, 1981.p.14).

Burton in 1865 wrote: 
The savage custom of going naked has denuded the mind and destroyed all decorum in the language. Poetry there is none...There is no metre, no rhyme, nothing that interests or soothes the feelings or arrests the passions...(cited in Finnegan, 1970.p.27).

Thomas Jefferson the third President of the United States (1801-1809), the principal author of the Declaration of Independence (1776), and one of the most influential Founding Fathers of America (http://en.wikipedia.org/wiki/Thomas Jefferson: accessed 10/02/10) remarked:

The blacks, whether originally a distinct race or made distinct by time and circumstances, are inferior to the whites in the endowments of body and mind ...(cited in Ngugi, 1981:14).

According to Ngugi, for the best and most sensitive minds of European culture, including Shakespeare's, the definition of social reality was rooted in their European tradition, history, race, culture and class and when they talked of man they meant the European man (Ngugi, 1981). Thus Jefferson's views above should not be surprising-- although the USA fought against Britain on the basis that all men were created equal they did not mean to include non-whites -these were too dark to be visible! This explains why black people continued to suffer slavery and racism in the land of the free. This also explains why David Livingstone 'discovered' what he named the Victoria Falls whose real name is Mosi oa Tunya, in spite of the fact that the local black guides and carriers of his luggage took him there. Naming the falls in honour of his distant queen illustrates how the blacks did not matter to him. In fact Africans needed to be exorcised of their heathen and backward practices and the school system shouldered this big responsibility. In schools

...the English language and English literature syllabuses were tailored to prepare the lucky few for an English degree at university... Shakespeare, Milton, Wordsworth, Shelley, Keats and Kipling were familiar names long before I knew I would even make it to Makerere (Ngugi, 1987.p.91)

As Ngugi (1987:93) notes the products of the school system's way of looking at the world, even the world of the immediate environment was Eurocentric. Europe was the center of the universe. The earth moved around the European intellectual scholarly axis (Ngugi,1987.p.93)

Post-colonial criticism seeks to resist domination and assert the humanity of the formerly oppressed. As aptly put across by Chidi Amuta (1989:6) 'Afrocentric literature tries to shake off the yoke of Eurocentricity which history has placed upon the shoulders of Africa'.

The negative perception about 'Dark Africa' such as exhibited in the following quotation influenced European writers the same way the media currently influences Western people about Africa:

The Natives being propagated from Cham (Ham), both in Visages and Natures, seem to inherit his malediction. Their colour is ugly black, are strongly limbd, desparate, crafty and injurious. Their heads are long; their haire, woolly and crisp...Their noses are flat, crusht so in their infancie; great lips, description cannot make them greater; quick ,crafty eyes...But these savages eat men alive or dead...(Thomas Herbert: 'Travels into Africa and Asia of 1638 cited in Flora Veit-Wild,2006.p.7)

Herbert above talks about 'great lips',Othello is described as having 'the thick lips'(Act 1 Scene 1 line 63);Herbert talks about 'these savages' Montano refers to Othello as a 'damned slave'(Act 5,Scene 2 line 241) and Lodovico, a high ranking Venetian nobleman describes Othello as 'a cursed slave' (Act 5,Scene 2 line 288);Herbert says 'their colour is ugly black' and Emilia talks about 'thou dull Moor'(Act 5,Scene 2 line 223). These are some examples which show that the attitude shown by Shakespeare towards people of colour, as reflected by his characters and reflecting his own attitudes as a human being, was not an isolated incident. The differences of people from different ethnic and racial groups brings about the concept of 'othering' which refers to 'the labeling and degrading of cultures and groups outside of one's own'(Riggins, 1997 cited in Jandt (2007:42).Jandt (2007:42) goes on to say that

as people create a category called 'us', another category of 'not us' or 'them' is created. The collective pronouns us and them become powerful influences on perception. The names given to 'them' can be used to justify suppression and even extermination.

Names given to black people in Zimbabwe and elsewhere in Africa such as 'native', 'baboon', 'savage','kaffir' were meant to characterize them as not only different but also inferior/subhuman and therefore not 'deserving' of a treatment which was normally given to 'normal' human beings. The Nazis labeled Jews 'bacilli', 'parasites', 'disease', 'demon' and 'plague' because 'although killing another human being may be unthinkable, 'exterminating a disease' is not' (Jandt,2007:42).We find a lot of this de-humanizing in the cited texts in order to justify different and unfair treatment.

\section{The Merchant of Venice}

The Merchant of Venice is believed by some critics to have been influenced by Marlowe's play The Jew of Malta which is based on a real historical figure, Joseph, Duke of Naxos (Walter,1960). Marlowe chooses to call him Barabas, completely falsifies his character and draws him according to the medieval pattern as a monster. Both Shakespeare and Marlowe should be seen at worst to be very much prejudiced against Jews. If they were not they danced to the gallery and created the monsters which their audiences relished to watch. If indeed he created the caricature called Shylock to please his paymasters, the Elizabethans, he should be charged for racism/Anti-Semitism and religious bigotry.

Some sources argue that The Merchant of Venice_was partly influenced by the trial and execution in 1594 of Roderigo Lopez a Jew and Queen Elizabeth's physician who had been a highly respected and trusted man until the enmity of the Earl of Essex ruined him (Walter,1960). The anti-Jewish climate prevailing during the trial might not have 
created atmospheric conditions favourable for a fair hearing for the condemned man especially bearing in mind that the Earl of Essex presided over the hearing (Lott,1962).

\section{A. Shakespeare's Handling of Shylock}

Antonio, the merchant of Venice, is approached by his bosom friend Bassanio who needs money to spruce up his image in preparation for his intended visit to woo Portia. Unfortunately all his ships are out and he cannot raise the 3000 ducats required. He then suggests that Bassanio finds money from whatever source and promises to pay back when his ships return:

Go presently inquire, and so will I,

Where money is, and I no question make

To have it of my trust, or for my sake (Act I, Scene 2 lines 183-5)

The search lands the two at Shylock's home. It is crystal clear from Shylock's utterances to Bassanio that there is deep-seated hostility between Christians and Jews. When, for instance, Bassanio invites Shylock to dinner the latter remarks sarcastically:

Yes, to smell pork, to eat of the habitation which your prophet the Nazarite conjured the devil into. I will buy with you, sell with you, talk with you, walk with you, and so following. But I will not eat with you, drink with you, nor pray with you (Act I, Scene 3 lines 28-32).

In an aside when Antonio enters Shylock declares:

I hate him for he is a Christian.

But more, for that in low simplicity

He lends out money gratis, and brings down

The rate of usance here with us in Venice

He hates our nation, and he rails

Even there where merchants must congregate (Act I, Scene 3 lines 36-43)

From the speech we get to hear of the deep-seated grudge he harbours for Antonio for being Christian, for lending out money interest-free and for hating/hurting him being a Jew. As readers we find the first two reasons deplorable but our view of him somewhat changes when we hear that Antonio also hates him and 'rails' where merchants congregate. We are persuaded to think that Antonio is no better. We should believe Shylock's utterance since it is an aside, which is like thinking aloud -- with no one 'in attendance' there is no reason for him to misrepresent facts. In fact Antonio goes on to call Shylock 'the devil' (Act I, Scene 3 line 93) and 'an evil soul' (Act I, Scene 3 line 94) in one breath to someone whom he wants to borrow huge sums of money from. This shows the audience how much Antonio abhors Shylock. As if this evidence of Antonio's not-so-Christian side is not enough Shylock accuses him thus:

You call me misbeliever, cut-throat dog,

And spit upon my Jewish garbedine

And all for use of that which is mine own. (Act I, Scene 3 lines 106-9)

Antonio does not deny the charges. Instead he threatens even more:

I am as like to call thee so again

To spit on thee again, to spurn thee too.

If thou wilt lend this money, lend it not

As to thy friends...(Act I, Scene 3 lines 124-6)

What happened to the Christian teaching of loving our enemies reflected in the following verses?

But I say unto you, love your enemies bless them that curse you, and pray for them, which despitefully use you and persecute you. (Mathew $5 \mathrm{v} 44$ ) and

And if you salute your brethren only, what do ye more than others? do not even the publicans so? (Mathew 5 v 47)

If Antonio did all the things Shylock accused him of doing to him, which we do not have even an inkling of doubt to suspect he didn't, is he not even worse than the person on whom he heaps insults and threats including spitting on his Jewish gabardine and beard?(Act I, Scene 3 line130).It seems Shylock stomachs all the insults stoically. If one gets so much in terms of insults and his heart hardens as a result can we really blame him? If he gets an opportunity to revenge and seizes that opportunity, bizarre as it might seem, do we not or should we not at least understand where he is coming from especially when the perpetrator threatens to heap even more insults? If Antonio has the audacity to threaten to spit in the face of a potential lender of 3000 ducats because of a difference of opinion on economic matters and religion who is the villain? Why did he 'stoop' so low as to borrow dirty money from a sworn enemy? Where were the 'good' Christians he dished out money to gratis in the past?

The strong aversion for Jews is not only confined to Antonio. Even clowns like Launcelot have a field day on how inhuman Jews are supposed to be when he says to his father:

My master is a very Jew. Give him a present? give him a halter? I am famished in his service; you may tell every finger I have with my ribs...I am a Jew if I serve the Jew any longer (Act II, Scene 2 lines 92-100).

The description 'Jew' is synonymous/associated with evil. Launcelot bids farewell to Jessica whom he describes as the 'most beautiful pagan, most sweet Jew'. By being beautiful, in Launcelot's view, facially and especially in the heart, she is an exception -- Jews are expected to be ugly! In Act II, Scene 4 lines 29-39 Lorenzo tells Gratiano and Salerio how Jessica will run away with him stealing her father's gold and jewels. Gratiano, a Christian, revels in breaking the 
seventh commandment (Exodus $20 \mathrm{v}$ 15) by stealing from his prospective father-in-law whom he describes as 'a faithless Jew'(Act II, Scene 4 line 37). In fact the triumphant Antonio, given the opportunity to render mercy to Shylock at the end of the trial proposes to keep half of what the latter possesses

to render it

Upon his death unto the gentleman

That lately stole his daughter (Emphasis added)(Act II, Scene 4 lines 379-81).

The gentleman is rewarded handsomely for stealing.

In fact more Christians are involved in the stealing of Jessica from her father as well as Shylock's money and jewellery. Launcelot, Shylock's former servant and currently Bassanio's, is sent to Shylock to purportedly invite him for dinner but the actual reason is to give Jessica ample time to loot Shylock's valuables. Doesn't all this Christian involvement in inflicting pain on him understandably radicalize him even further and deepen the fissure between the two antagonistic groups?

Solanio, like Antonio, describes Shylock as 'the villain Jew' (Act II, Scene 8 line 4), 'the dog Jew'(Act II, Scene 8 line14) and 'Old carrion' (Act III, Scene I line 29) and describes Antonio thus:

...without any slips of prolixity, or crossing the plain highway of talk, that the good Antonio, the honest Antonio-O that I had a title good enough to keep his name company(Act III, Scene I lines 9-12).

He goes on to say 'let me say 'amen' betimes, lest the devil cross my prayer, for here he comes in the likeness of a Jew' (Act III, Scene I lines 17-18).

The merchant of Venice, Antonio, is depicted as a saint while Shylock is seen as the devil. The phrase 'he (the devil) comes in the likeness of a Jew' tends to generalize as if all Jews are carbon copies of each other in terms of their behaviour.

If Antonio has done what Shylock in the following speech says he did there is no reason to characterize him, like his one-sided Christian friends do throughout the play, as a spotless blemish-free victim. We have no reason to doubt what Shylock says here to Salerio and Solanio, two of Antonio's friends:

He hath disgraced me, and hindered me half a million, laughed at my losses, mocked at my gains, scorned my nation, thwarted my bargains, cooled my friends, heated mine enemies, and what's his reason? I am a Jew. Hath not a Jew eyes? Hath not a Jew hands, organs, dimensions, senses, affections, passions? Fed with the same food, hurt with the same Winter and Summer, as a Christian is? If you prick us do we not bleed? If you tickle us do we not laugh? If you poison us do we not die? And if you wrong us shall we not revenge? (Act III, Scene I lines 44-54).

Salerio and Solanio do not dispute the allegations leveled against their 'superhuman' friend. In fact when Tubal approaches Solanio he instead says 'here comes another of the tribe; a third cannot be matched, unless the devil himself turn Jew' (Act III, Scene I lines 63-4). This utterance reveals racism at its zenith.

In Act III, Scene I we are informed about Jessica and Lorenzo's extravagance. In Genoa she is reported to have spent 'fourscore ducats'? (Act III, Scene I lines 89-90) and sold the ring her father got from Leah her mother (presumably a wedding or engagement ring, a priceless heirloom) for a monkey. Is such extravagance called for or defendable? Shylock might be miserly but is unbridled extravagance (the kind which reminds one of the prodigal son's escapades) especially of ill-gotten wealth, not equally nauseating? In fact the prodigal son was better since he was squandering his share -- Jessica and Lorenzo had plundered it from Shylock's coffers.

In the court scene alone (Act IV Scene 1) there are 23 references to Shylock's ethnicity. On one page alone or within the space of 31 lines 'Jew' is mentioned eight times. One wonders whether the issue is about the bond per se or about race: Shylock dares to touch the untouchable and the untouchable have ganged up. Instead of referring to him by name, the Duke, Portia, Antonio, Bassanio and Gratiano among others, refer to 'the Jew'. Besides this there are other denigrating characterizations that are made such as 'a stony adversary, an inhuman wretch' (by the Duke (of all people!) in line 4), 'harsh Jew', 'inexecrable dog' and 'currish Jew' (by Gratiano in lines123, 128 and 288 respectively), 'cruel devil' and 'this devil' (by Bassanio in lines 213 and 283 respectively). The Duke of Venice says to Antonio:

I am sorry for thee, thou art come to answer

A stony adversary, an inhuman wretch,

Uncapable of pity, void and empty

From any dram of mercy (Act IV Scene 1 lines 3-6)

The Duke goes on to say: 'Go one and call the Jew into the court' (Act IV Scene 1 line14).

Reference to 'the Jew' has an effect of amplifying the differences or perceived differences between the Christians and the Jews. With such bias one wonders what kind of treatment Shylock will receive with the Duke among those demonizing him thus. In one breath the Duke pleads on behalf of Antonio whom he describes as 'a royal merchant' (Act IV Scene 1 line 29) and expects 'a gentle answer Jew' (line 34) as if 'Jew' refers to 'something' certainly subhuman. The clerk reads Bellario's letter, which in part reads '... his name is Balthazar. I acquainted him with the case in controversy between the Jew and Antonio the merchant' (Act IV Scene 1 lines 153-155). When Portia (Balthazar) is called upon she asks: 'Which is the merchant here? And which the Jew?' (Act IV Scene 1 line 170) and a few moments later she says 'Then must the Jew be merciful'(Act IV Scene 1 line 178). 
The use of the description 'the Jew' is consciously or unconsciously putting a huge wedge between the majority (the 'Christians') and the Jews who are in the minority. That phrase has an effect of putting the 'Christians' on a moral high ground and of 'othering' the Jews who do not seem to measure up. Is it necessary for Balthazar to say to Shylock:

Take then thy bond...

But in the cutting it, if thou dost shed

One drop of Christian blood, thy lands and goods

Are by the laws of Venice confiscate

Unto the state of Venice (Act IV Scene 1 lines 305-8)

Is Christian blood better than any other? If the altercation were between two Jews would the court's reaction be different?

Asked by Portia (Balthazar) what mercy Antonio can render Shylock, Antonio says, among other conditions, that Shylock 'presently become a Christian' (Act IV Scene 1 line 383).

Antonio forces Shylock to be a Christian. 'Normal' Christian teaching requires one to freely choose to be one. If one is forced, as in the case of Shylock, one may just pay lip service to the faith to save one's skin instead of the soul therefore Antonio's requirement smacks of religious bigotry. Shylock's answer, 'I am content' (line 389) after he is asked if he agrees to Antonio's terms should be seen as an utterance squeezed out of one who is cornered and thus comes from the mouth not from deep down his heart. This explains why his next utterance is to ask for leave to go since he is no longer feeling well. A true convert should be filled with joy not forlorn -- conversion shouldn't be punitive. The holierthan-thou attitude adopted by the so-called Christians in The Merchant of Venice, which may be a reflection of the Elizabethan Christian, is ill-advised. Its arrogance, militancy and intolerance outlived this era. This mentality was displayed in the Anti-Semitism of Germany in the 1930s and 1940s and is also evident even today: the worldview of the economically powerful is the worldview, the religion of the economically powerful is the religion, the culture of the economically powerful is the culture etc. The unipolar world threatens to uniformize everything and those out of the circle are not only denigrated but also demonized and concerted efforts are sought to sponsor, financially and militarily, those who have 'the right way' of doing things. The key court scene is a farce: Portia is unqualified to practise law. The letter from Bellario that introduces her as Balthazar a trained lawyer is a piece of fraud. She 'grants' Shylock his wish, that is, to have the pound of flesh but without shedding, not just ordinary human blood but a 'drop of Christian blood'. What human flesh can exist without blood? Isn't this argument seriously flawed? The court scene is meant to rescue Antonio, a 'Christian'? at any cost but may not be, legally speaking, sound.

The discussion has so far attempted to shed light on Shylock's 'villainy' and to show that if he indeed is a villain, he is not the only one in The Merchant of Venice. At the receiving end of xenophobic, racial and religious attacks Shylock gets a rare opportunity to revenge when one of his erstwhile tormentors fails to pay back what he owes him. The Antonio-Shylock altercation is not about the unpaid 3000 ducats, this is only the catalyst .Shylock is too rich to have sleepless nights over that amount. The issue is about human dignity. The handling of the characterization of Shylock shows that at worst Shakespeare had entrenched prejudices against Jews and at best he was dancing to the Elizabethan audience's racist dictates. The latter argument suggests that the Elizabethans had terrible attitudes towards Jews whom they saw as the devil incarnate. So Shakespeare by depicting Shylock thus was simply playing to the gallery. If indeed he was, that is unfortunate -- that action makes him no better than his audience and the racist and ethnocentric breed of characters be created.

\section{B. Shakespeare's Handling of The Prince of Morocco}

Shakespeare, through one of the key characters, Portia, displays a racist attitude towards the people of colour through his handling of the Prince of Morocco. When the serving- man announces the Prince of Morocco's imminent arrival she responds: 'If he have the condition of a saint and the complexion of a devil, I had rather he should shrive me than wive me'(Act I Scene 2 lines 110-112).As far as Portia is concerned Blacks have the complexion of a devil and given her way she would not entertain a black person for a husband. The announcement of the Prince of Morocco's imminent arrival (Act I Scene 2 line 105) comes immediately after Portia and Nerissa approvingly discuss Bassanio as the most eligible suitor (Act I Scene 2 lines 95-102). This is meant to create anxiety among the Elizabethan audience upon the possibility of Portia being 'won' by one who has the 'complexion of a devil' ahead of the blue-eyed boy, Bassanio, whom she wants to 'coach' on how to choose correctly when he comes. She says:

I would detain you here some month or two

Before you venture for me. I could teach you

How to choose right...(Act III Scene 2 lines 9-11).

Some critics contend that the music played when Bassanio is going through the caskets which has conspicuous 'd'sounds and the message it contained may have been assistance enough for Bassanio. In fact Portia's imploring of Bassanio to be careful in his choice is meant to tell him, albeit subtly, not to fall into the popular trap of associating the glittering gold with the solution. If one stops someone who is at the verge of committing himself/herself to a certain choice and tells him/her to be careful the real meaning /effect is to tell him/her to stop, reconsider and think differently (and unordinarily) and this is help coming at the most opportune moment. All this was meant to assist the blue-eyed boy to choose correctly. When the Prince of Morocco fails to choose the right casket, Portia is greatly relieved and says:

A good riddance. Draw the curtains, go 
Let all of his complexion choose me so (Act II Scene 7 lines 78-9).

She wishes all black suitors who might come in future would choose wrongly so that she is saved? from marrying into the wrong race. Portia's characterization of blacks as having the complexion of a devil is reflected in much later works and general attitude of the European towards 'The Dark Continent' as evidenced by for instance Kipling's notorious poem 'The White Man's Burden' in which the poet implores:

Take up the White man's Burden-

Send forth the best ye breed-

Go send your sons to exile

To serve your captives' need...

Your new-caught, sullen peoples,

Half devil and half child

(Cited in Eliot, 1962 .p.143)

The attitude expressed in this poem

'...was not an isolated image concocted by Kipling. Rather it was an accurate articulation of European colonial consciousness which was amply represented not only in the popular literature of the day but also in the enduring conceptions and speculations of modern European thought... (emphasis supplied) (Serequeberhan,1995.p.4)

Sifuna and Otiende (1994) have this to say about this 'enduring conception':

The view held by many Europeans who first came to Africa...was that the African was a savage, a pagan with no history and culture to perpetuate, that he knew nothing... (p. 129)

This is what Cecil John Rhodes, the founder of the British colony of Rhodesia (now Zimbabwe) said about the issue of imperialism that inevitably led to the denigration of other peoples and the subjugation of anything associated with the colonial subjects:

I contend that we are the finest race in the world and that the more of the world we inhabit the better it is for the human race. Just fancy those parts that are at present inhabited by the most despicable specimens of human beings what alteration there would be in them if they were brought under Anglo-Saxon rule? (Emphasis added) (Atkinson, 1972. p.5)

The colonized therefore 'owed' the colonizer gratitude for colonizing him/her since this brought enlightenment hence the 'minimum' force used to drag the non-white from the dark cave (Plato's allegorical cave?) was inevitable and should be understood by all level-headed beings! Hence the Shylock types had to be dragged to the light by forcing them to renounce their religion for 'the religion'.

When any artist chooses to allot some of the most controversial utterances to one of the most important characters he/she risks being (mis)understood. Portia is depicted as flawless -- she is a paragon of beauty, witty, wealthy and extremely intelligent. In the space of a few hours, for instance, she acquaints herself with Venetian Law and outshines those who have studied law and have been in practice for years. If this 'perfect' and therefore likeable character is then given racist lines to speak then the audience are likely to condone such behaviour associating it with the playwright's beliefs. The audience is forgiven for equating a main character's utterances and actions with those of the creator of that character especially when there are no 'sanctions' on the character. Portia is some kind of a messiah who snatches Antonio from the jaws of death (since he would have certainly bled to death from the extraction of the pound of flesh from nearest his heart) an action that endeared her to the audience. Unfortunately she is blatantly racist and so was her creator, Shakespeare. The messiah is only for those of a certain skin pigmentation.

\section{DEPICTION OF OTHELlO}

The protagonist in Othello is a black man who is a highly capable General in the Venetian army who secretly marries Desdemona without even the knowledge of her father, Brabantio. The fact that the well-respected General does this speaks volumes about the racial relations between the whites and non-whites. The two might have been too afraid to marry openly. When the father hears about it he raises hell. It is understandable to be deeply upset but it is uncalled for to be racially abusive to the 'perpetrator'. He refers to his daughter's husband as 'the Moor' and he also accuses him of witchcraft several times and describes the union as 'treason of the blood' (Act 1,Scene 1 line 166). On the supposed link between blackness and witchcraft he says: 'Damned as thou art thou has enchanted her' (Act 1,Scene 2 line 63). It is inconceivable to Brabantio for 'fair' Desdemona to accept Othello, a black person and therefore a 'black magic' practitioner, as husband, unless she has been subjected to black magic. We learn that Brabantio had spurned Roderigo's proposal as his son-in-law (Act 1,Scene 1 lines 93-95) but now he has suddenly made a U-turn because a black man has won her heart. He wishes Desdemona had been married to the Venetian: 'O, would you had had her!' (Act 1,Scene 1 line 172) and goes on to refer to him as 'good Roderigo' (Act 1,Scene 1 line 180) and now teams up with him to manhunt or 'moorhunt' the 'fugitive'. He asks Roderigo:

Do you know

Where we may apprehend her and the Moor? (Act 1,Scene 1 line 173).

Othello here and elsewhere is 'othered' -- he is not referred to by name. Like the use of the term 'the Jew' in The Merchant of Venice, the term 'the Moor' is used in order to show how different and inferior the referent is. 
As the villain, Iago's utterances will only be referred to in passing since he is not the best character to represent the playwright and societal attitudes of his time. However Iago's racial attitude is no different from most other characters. He implores Brabantio and other Venetians within earshot:

Arise, Arise!

Awake the snorting citizens with the bell,

Or else the devil will make a grandsire of you

Arise I say! (Act 1,Scene 1 lines 84-87).

The snoring citizens are implored to wake up and prevent the unfortunate incident which is about to happen that is, the devil marrying angelic Desdemona resulting in the two having 'strange-looking' offspring who will obviously be Brabantio's grandchildren. He goes on to taunt him thus:

...you'll have your daughter covered with a

Barbary horse, you'll have your nephews neigh

to you, you'll have coursers for cousins, and

gennets for germans (Act 1,Scene 1 line 108-11)

Othello is depicted in animal terms, a beast of burden and war, not a human being; if human he is just a 'knave of common hire, a gondolier' (Act 1,Scene 1 line 21). As it is, for the Venetians, he is good as a hired 'mercenary' to ward off their enemies. One has the feeling that he is just as good as a dog that is kept for convenient utilitarian reasons. Unfortunately the dog has overstepped its sphere of operation hence the hysterical reaction by Brabantio. Iago may be the villain in terms of his catalytic role in turning Cassio against Othello and Othello against Desdemona but his attitude to race seems to be shared by many other characters hence his call for action is taken up to the Duke. The reader should be forgiven for concluding that the characters share the playwright's and his contemporaries' racial intolerance.

The First Senator says: 'Here comes Brabantio and the valiant Moor' (Act 1,Scene 3 line 47). This may seem to be a compliment at surface level but upon close scrutiny it isn't that: why the reference to ethnicity in Othello's case? Desdemona refers to 'the Moor my Lord' (Act 1,Scene 3 line 187) as if their relationship is based on her fascination with a man from a different racial and physical background. A few lines later she talks about how much she loves 'the Moor' (Act 1,Scene 3 lines 244-255) before she talks about seeing 'Othello's visage in his mind' (Act 1,Scene 3 line 248) indicating that she loved the inner person but her continued reference to his ethnicity makes the observant critic uneasy. The mentioning of 'the Moor' can be seen as a slip of the tongue/mind-slipping from the unconscious-the 'moorness' is what attracted her to Othello -- this explains her obsession, whether conscious or unconscious, with him as shown by her addressing him with reference to his skin colour.

The Duke after hearing Othello and Desdemona express their commitment to each other 'comforts'/ 'reassures'? Brabantio thus: 'your son-in-law is far more fair than black' (Act 1,Scene 3 line 286). Blackness is associated with evil but this 'their'? black person according to the Duke, is an exception. Immediately after the Duke's utterance the First Senator says: 'Adieu, brave Moor. Use Desdemona well' (Act 1,Scene 3 line 287). There is a conscious or unconscious Negrophobia that the fair and delicate lady is in the wrong arms which are too coarse to handle her comfortably and that the General needs to be reminded on civilized handling of sophisticated women.

In Act 2, Scene 2 Third Gentleman describes Othello as 'the warlike Moor Othello'(Act 2,Scene 3 line 28) and Cassio, Othello's blue-eyed boy and confidant '...prays the Moor be safe'(Act 2,Scene line 33) and goes on to say:

Thanks, you the valiant of the warlike isle

That so approve the Moor, O, let the heavens

Give him defence against the elements (Act 2,Scene 1 line 43-45).

Even those who are supposed to be very close to him are consciously or unconsciously distanced from him. In the space of seven lines that is from Act 2 Scene I line 27 to line 33 the term 'the Moor' is mentioned three times.

Montano, the Governor of Cyprus and therefore an eminent person, says about Othello's choice of Cassio:

And 'tis great pity that the noble Moor

Should hazard such a place as his own second (Act 2,Scene 3 lines 134-135).

It is always 'the Moor' not the General or Othello. Other examples are Emilia (Act 3,Scene 1 line 43) and Lodovico, a high-ranking Venetian noble(Act 4,Scene 1 line 260). Othello himself is given words which denigrate his blackness:

Yet I'll not shed her blood

Nor scar that whiter skin of hers than snow

And smooth as monumental alabaster (Act 5,Scene 2 lines 3-5)

The above speech reflects an inferiority complex and the 'worship' of the white skin. Like Desdemona he is also consciously or unconsciously fascinated by one who has a different skin colour. Almost four centuries after Othello was written the same fascination with crossing the racial divide is revealed in The Autobiography of Malcolm $X$ when Malcolm X drops Laura, his black girlfriend, for Sophia, a white one in order to improve his social standing. Malcolm $\mathrm{X}$ says about it: '...in my black ghetto in America, to have a white woman... was for the average black man, at least, a status symbol of the first order...' (Haley and Malcolm X, 1964.p.67)

\section{CONCLUSION}


When the majority of characters in Othello choose to refer to another character by referring to his ethnicity instead of his name there will be a problem. There is a worse problem when because of the character's skin pigment he/she is demonized, not by just one character who might understandably have a personal axe to grind with him but also, by almost the entirety of the 'Who's Who' of the play. When the latter happens the critic should be forgiven for concluding that the artist shares whatever attitudes are displayed by his creations, the characters.

Shakespeare's handling of race especially in The Merchant of Venice and Othello reflects deep-seated prejudices that he shared with his paying audience that he sought to please. One wonders on the 'comedyness'? of The Merchant of Venice when during the rigged court session and amidst jeering Shylock is not only stripped of his wealth but, more importantly, also of his dignity and identity. As if in the mishandling of Shylock Shakespeare has not exposed his ethnocentrism enough, he brings in The Prince of Morocco who has 'the complexion of the devil' and who is 'a gentle riddance' to the 'angelic' Portia when he fails to choose the correct casket. A more balanced handling would have seen Shylock seeing the folly of being consumed by revenge without being coerced and Antonio acknowledging his contribution in the near-tragedy and the two embracing in reconciliation. Such a handling could also rid the play of the implicit and explicit references to race and ethnicity in denigrating terms.

\section{REFERENCES}

[1] Atkinson, N.(1972). Teaching Rhodesians. London: Longmans.

[2] Chidi Amuta. (1989). The Theory of African literature: Implications for Practical Criticism London Z.E.D. Books.

[3] Eliot, T.S. ed. (1962). A Choice of Kipling's Verse. London: Anchor Books

[4] Finnegan, R. (1970). Oral Literature in Africa. Oxford: Claredon Press.

[5] Haley, A and Malcolm X. (1964). The Autobiography of Malcolm X. New York: Heinemann. http://en.wikipedia.org/wiki/Thomas_Jefferson accessed 10/02/10

[6] Jandt, F. E.(2007). An Introduction to Intercultural Communication Identities in a Global Community. London: SAGE Publications.

[7] Lott, B. (Ed) (1962). The Merchant of Venice. Harlow: New Swan Shakespeare.

[8] Ngara, E. (1990). Art and Ideology in the African Novel: A Study of the Influence of Marxism in African Writing. London: Heinemann.

[9] Ngugi wa Thiong'o. (1981). Writers in Politics. London: Heinemann.

[10] Ngugi wa Thiong'o. (1986). Decolonizing the Min. Harare: College Press.

[11] O'Connor, J. (2003). New Longman Shakespeare Othello. Essex: Longman.

[12] The Holy Bible: Dictionary and Study Helps-Authorized King James Version. (1989). New York: World Bible Publishers, Inc.

[13] Serequeberhan, T.(Ed) (1995). African Philosophy: The Essential Readings. New York: Paragon House.

[14] Sifuna, D.N. and Otiende, J.E. (1994). An Introductory History of Education. Nairobi: Nairobi University Press.

[15] Thomas Herbert: 'Travels into Africa and Asia' of 1638 (cited in Flora Veit-Wild, 2006) Writing Madness: Borderlines of the body in African Literature. Weaver Press. Harare. www.enotes.com/../introduction accessed on 18/11/09

[16] Walter, J.H. (1960). The Merchant of Venice. Oxford: Heinemann Educational Books.

Mika Nyoni is a lecturer in the Curriculum Studies Department at Great Zimbabwe University, Off Old Great Zimbabwe Road, P.O. Box 1235, Masvingo, Zimbabwe. His research interests are in Literature, Sociolinguistics and Semiotics. 